DIGITAL COMMONS
@ UNIVERSITY OF SOUTH FLORIDA

Volume 2

Issue 1 Volume 2.1 (Spring 2012): Open Access

\section{ABO: Interactive Journal for Women in the Arts, 1640-1830}

2012

\title{
Place and Contemplative Pedagogy
}

\author{
Laura Runge \\ University of South Florida, runge@usf.edu
}

Follow this and additional works at: https://digitalcommons.usf.edu/abo

Part of the Dramatic Literature, Criticism and Theory Commons, Educational Methods Commons, Feminist, Gender, and Sexuality Studies Commons, and the Literature in English, British Isles Commons

\section{Recommended Citation}

Runge, Laura (2012) "Place and Contemplative Pedagogy," ABO: Interactive Journal for Women in the Arts, 1640-1830: Vol.2: Iss.1, Article 12.

http://dx.doi.org/10.5038/2157-7129.2.1.11

Available at: https://digitalcommons.usf.edu/abo/vol2/iss1/12

This Pedagogy is brought to you for free and open access by Digital Commons @ University of South Florida. It has been accepted for inclusion in ABO: Interactive Journal for Women in the Arts, 1640-1830 by an authorized administrator of Digital Commons @ University of South Florida. For more information, please contact digitalcommons@usf.edu. 


\section{Place and Contemplative Pedagogy}

\section{Keywords}

ASECS, feminism, feminist criticism, feminist theory, pedagogy, place

Creative Commons License

(c) (i) $\odot$

This work is licensed under a Creative Commons Attribution-No Derivative Works 3.0 License. 
I recently observed an intro to lit class taught by a Graduate Teaching Assistant in which a young undergraduate presented a brief biography of Gwendolyn Brooks and announced that she had no idea how the biography related to the poem "We Real Cool," "unless" she said, "it has something to do with race." Struck by the enormous blindness of the observation, I tried to determine if the student refused to connect the issues of race and gender in the poem to an historical context of racism and sexism in our society because she is "over" race and gender, or because she is so deeply entrenched in racist, sexist perspectives that she failed to see the tensions illustrated in the poem. Later, I continued to think about this young woman, and I reached an assessment that I prefer: rather than deeply racist and sexist or pathologically banal, I think the student is simply afraid of the immense power and pain associated with racial and gendered conflict in our society - perhaps in her own life. Such fear has a way of paralyzing the analytic brain, creating a radical disconnect between the student and the text. In this paper, I want to talk about diagnosing the disconnect and some strategies I've found useful in giving students access to their emotional responses to texts.

Something the teachers on this panel all note is a recent sense of fatigue around feminism in the academy. I sometimes sense fatigue in my students (undergraduate and graduate) when it comes to issues of race, class, and gender. They remain interested in marriage and sexuality, but they find feminism or race issues difficult to articulate in class. At the graduate level, this manifests in a fear of being labeled sexist or racist and being confused as to how to avoid the label. At the undergraduate level, it manifests in grand obtuseness - as illustrated above - or by discomfort or truncated, "safe," discussions on gender and race. This fatigue parallels the shift in critical trends over the past decade, a move from openly feminist themes and issues, to broader political analysis that incorporates feminist theory and critical race theory into globalization, disability, ecocritical and various historicist studies. I, for one, welcome the diversification of feminist issues and the inclusion of gender analysis in problems that might not have seemed "feminist," such as ecocriticism. As scholars we have learned a great deal through feminist analysis of the literature of the eighteenth century, and there is certainly more to learn. But we have successfully complicated the picture, so that there is little room for universal cheerleading for a new female author; we have discovered and analyzed a range of women's views and views on women across the political, social, and religious spectrum, some of them less appealing than others. The picture of feminism is more complicated, perhaps, than at its entry into higher education in the seventies, which may contribute to fatigue. However, I also suggest that we might understand this fatigue as a symptom of the disconnect resulting from fear.

Because of my administrative load, I generally only teach graduate students. I am teaching an undergraduate Brit Lit survey of $17^{\text {th }}$ and $18^{\text {th }}$ century literature this term, the first time in four or five years. I should add that I teach at a large, urban state university in the southern US, and that we have an unusually high level of ethnic diversity in our student population. I am trying out two new strategies for connecting with this generation of undergraduates and making early modern literature meaningful for them, which I will outline briefly here. At the start, though, let me say that I find the students to be bright, engaged and informed, particularly on gender issues. It seems to be an area that they want to discuss, though I find that they are limited in how they can do so. In other words, they are doing feminist criticism without being very aware of it. They feel reasonably comfortable identifying the sexism of Milton by saying it was the way things were "back then," though they don't always agree on this. My goal is to get them to see how issues of 
gender, sexuality, race, and class play into who we are today and how we read the literature of the past. To do that, I have built into the course information about place and place theory, and I have introduced some contemplative strategies in the classroom.

The first strategy I will discuss, then, is my use of the thematic focus on place, the construction of place within the text and for the text in history. The gap between the historical past of literature and the cognitive needs and pleasures of today's readers poses a well-recognized tension for teachers and scholars. Place provides a conceptual parallel to literature that students might easily grasp in its common-sense meaning. In other words, students can locate a place like Suriname, for example, on the map and find images and information about its present. A student might even physically visit the place or actually come from Suriname. It is locatable now.

Borrowing from the discipline of human geography, "place” can be understood as a geographical location invested with meaning in a context of power, and most geographers link place to human meaning and experience. Place is both human product and consumption; it is also a way of being, rootedness and authenticity, as in concepts of home or "my place" (Cresswell 12). Thus, it is at once locatable and subjective. Concerns over the compression of time and space, as witnessed by global commerce, travel, and digital communications, have led geographers to conceive of place as always in process and never complete. Memory and cultural productions, such as literature, play fundamental roles in this continuing process of construction of meaning in place.

By attending to the ways in which a seventeenth- or eighteenth-century text constructs place, we foreground more than setting. ${ }^{1}$ Indeed, seeing "place” as always in process, literature becomes a part of the cultural production of meaning in place, and as such provides access to analyzing the power dynamics that structure space, as well as the ways of knowing and being that belong to the humans in place. The illustration of power dynamics that structure space requires gender and critical race theories to understand how a text, such as Oroonoko, constructs place. Literature offers a profound and detailed interaction - between the author and the geographical location that potentially yields enormous information about the historical process of making a place; moreover, the act of reading this literature becomes a reiterated practice that is also constitutive of place. Making students conscious of their part in place-making is one aspect of drawing their connection to the early modern text. Thus the construction of place can be understood productively on at least two levels: within the early modern text itself and in the contemporary interpretation of the text in the classroom. In the first case, the attention to place highlights aspects of our geographical world that still exist and gives students access to its history. In the second case, students bring their awareness to how they come to know a place and the various power dynamics in which they participate.

I have structured my course readings to be able to develop the idea of an Atlantic Enlightenment that foregrounds political conflicts of gender, religion, colonialism, race, class, and ecology. I provide students texts to understand contemporary and historical theories of place, and I introduce these ideas through lecture and discussion. Students are building an understanding of the way to interpret seventeenth- and eighteenth-century literature through constructed notions of place. Then, something as simple as using Google Earth to bring the students visually to the place in the text allows them a valuable connection. 
The second strategy is more generally a set of methods belonging to a tradition of contemplative pedagogy. Returning to the student example with which I began, I believe many of the problems students face in analyzing literature for issues of gender, race, and class are fundamental problems of connection. I believe students fear drawing attention to themselves and controversial issues for multiple reasons: fear of their own strong emotions (anger, sadness, outrage, disgust, loathing), fear of being isolated in or for those feelings, fear of social repercussions for raising problems, and fear of judgment, whether by peers or by the instructor. Students fail to take risks because of these fears. In such a classroom, teachers witness student fatigue, disinterest, inability to engage in provocative exchanges, etc. Authentic learning requires risk; genuine engagement with literature requires connection. How do we get students over the problems of disconnection?

In contemplative pedagogy, the ideal is one of silent reflection and judgment-free discussion. By creating space in the class for silence and deep concentration (reading, listening, thinking, writing), students have the opportunity to respond to literature on a deep level, to sort through first responses and continue to the stickier issues. The judgment-free atmosphere - admittedly one that I am still working on - encourages students to explore ideas and feelings with less fear of repercussions. The activities aim toward training the students to take responsibility for their critical thinking and learning.

What follows are some examples of how I implement these contemplative strategies.

Opening meditation: Each class begins with five minutes of silence. I invite students to close their eyes and make themselves comfortable, and I guide them through a five-minute focus exercise. After it is over, I remind them of the purpose and benefit of slowing down the mind and clearing away the noise in order to focus on learning. This can be awkward, but I actually found that most students really appreciate this as a transitional time.

Response writing: After a discussion or an active-learning exercise (such as dividing the class into "roles" for Paradise Lost and doing a dramatic reading of the temptation scene), I give students five minutes to reflect on the experience. I don't require them to read their response to anyone or turn it in, but I ask if anyone wants to share her or his thoughts. This generally leads to a discussion of what and how they learned.

Recursive reading: Assigning a text or part of a text for a series of readings in class; beginning with a silent reading, then reflection, followed by a volunteer reading, then reflection, followed by a jump-in reading and reflection. Again, I ask for volunteers to discuss observations on what we learn by rereading. As you see, the contemplative practices involve slowing down the processes we normally use in the classroom and allowing for the time it generally takes for the lessons to sink into awareness.

Ending reflection: before leaving I ask students to write down at least one thing that they learned that day and that they will carry away from the class. This is particularly difficult to squeeze into a full, discussion-oriented class, but I believe it is a valuable exercise that asks students to be responsible for what they learned. It is not in the teacher's interest, however, to review these writings. 
I've also taken students on field trips and given them contemplative assignments such as a sense inventory: in pairs a student will take turns closing her/his eyes and describing out loud to the other person what she/he hears, smells, feels, and then silently write about what she/he sees. They share their responses with the group after coming back together. This works particularly well when the class is focused on a place that is connected to a text or an historical context.

Text mediation - this is an assignment where an instructor asks students to draw what is described in a text, or create a poem from a narrative, or the like. For example, after discussing William Bartram's use of illustration, I had students draw a description from Bartram's Travels in Florida. The translation into another form requires deep consideration of the verbal text and taps into the creative, emotional responses to the material. As in the other exercises, no judgment is made on the skill or evaluative quality of the student's work. Rather, discussion is used to illuminate connections to the work.

How is this feminist? By allowing students to explore their responses to the work, they begin to trust their judgment and to explore the emotional dimensions of a work. They begin to move through their fear and share their ideas with others. It is particularly useful with literature that takes on difficult subjects, like death, violence, abuse of humans or animals, genocide. As an instructor, I guide them to see the ways in which our responses are conditioned by our own subject positions, and how historical contingencies shaped by power dynamics directly affect them and the texts. It opens up possibilities for genuine connection that can be revealed to be feminist in practice already, and it promotes deeper consideration of these texts from the students' perspectives. It also promotes toleration of difference and respect for other people in the class.

There are some difficulties with these practices and some fundamental obstacles that I am still debating myself. In the first place, I like to talk. One of the reasons I went into the profession is because I enjoy discussing literature with other people. I appreciate the importance of silence and the real value of those quiet moments for the particularly shy or uncomfortable students. But I get excited, and my enthusiasm bubbles over into lively discourse. I sometimes think that my demeanor is anything but contemplative. I am certainly not modeling contemplative approaches as a rule.

Another issue is time. Just as with other forms of active learning, contemplative strategies require a great deal of classroom time which prevents the class from covering numerous texts. Going into it, the instructor needs to keep her expectations for coverage low, but the smaller number of texts is offset by the deeper connection to the texts and, hopefully, a skillful practice in reading.

Perhaps the biggest difficulty lies in achieving the ideal of non-judgment. I like to judge; it's part of my training. I find it very difficult not to praise work well done or to indicate disapproval in some - usually nonverbal—way if I find the answer /response inadequate.

I also find it challenging to reconcile judgment-free acceptance with critical thinking. This is a deep divide for me, and one that I have to confront. I actually think this problem has feminist dimensions as well, in terms of validating reason over emotion, fact over imaginative or 
collaborative solutions to problems. Feminists, particularly of eighteenth-century literature and culture, have long pointed to the oppression of women because of systematic associations of reason with men and emotion with women. While contemplative pedagogy is intended to break down Cartesian dualism by validating ways of knowing that come through the body as well as the mind, it risks looking frivolous or unserious in abandoning the authoritarian methods of the academy. With contemplative practices, the evaluation of student work turns on different priorities, such as engagement. I find that I cannot grade contemplative work, but simply count it as an activity that is completed. I have to remind students that the ideal of non-judgment is a temporary space that allows for multiple perspectives; it may not be the end point of learning. Consequently, I believe that contemplative strategies will always be part of a mixture of pedagogical techniques that I use in the classroom. At some point, I want my students to be able to think and write critically.

Because of its clearly alternative techniques, some students will resist. At least one student expressed vehement opposition to the methods, claiming that I was the expert, and he wanted to hear what I knew about the literature, not what his classmates thought. I explained that I was teaching the students "how" to analyze, not simply "what" to think. He wasn't buying it because he understood learning according to the banking model: because I had a PhD, I was a font of information from which he would imbibe and become enriched. Some students are connected in such ways, but I would argue that the majority are not. I believe the majority of students benefit from the practices that slow us down and ask us to recognize that we are humans with bodies as well as minds sitting next to each other in a classroom responding to a text.

I actually bring together the concepts of place and contemplative pedagogy by asking the students to be aware that the classroom is our space for the 75 minutes we share together twice a week. We appreciate that under other circumstances, we would probably not be together, but because of these texts and this class, we are a community for now. We devote our attention to our task in this place, and we each contribute to making this a unique place constituted by the diverse and wonder-full people that we are.

Remembering the young woman in my graduate student's class who failed to see a connection between Gwendolyn Brooks's life and her poem, I want to emphasize that we are witnessing problems of connection in the classroom that might look like other things: fatigue, disinterest, obtuseness. As feminist teacher-scholars, we share a goal of addressing the disempowerment of oppressed populations, many of whom are present in our classrooms. The ideas I've shared here are aimed at bringing our awareness to this student population and their experience of multiple subject positions. The combination of place-centered teaching and contemplative pedagogy provides unique ways to give students of this generation access to eighteenth-century texts, but also to our world and its history, and most importantly, to themselves.

\section{Conclusions:}

During the discussion following the session at ASECS, it was noted that there was a certain homogeneity among the presenters, not only in race but in relative age and career advancement. The panelists shared a sense of being in mid-career, which, perhaps, afforded them the opportunity to reflect on their teaching practices and, more importantly, to question how things 
are done. The panelists teach in a range of institutional settings, most varied in geographical location, and they shared a sense of regarding teaching as context-specific. So, while there was much to be gained here, there are also voices from other feminist scholars that need to be heard. Many ideas were generated through discussion, and we encourage readers to participate by posting responses and questions to the published papers. Please also review the materials these contributors have added to the Pedagogy Share Center.

Other essays in this series:

Introduction

Accessing Liberal Education

Gender and Genre

Dangerous Delusions

Notes

1. I have articulated some of these ideas with reference to Oroonoko in "Constructing Place in Oroonoko," in Gender and Space in Britain, 1660-1820, ed. Karen Gevirtz and Mona Narain, under review.

Works Cited

Cresswell, Tim. Place: A Short Introduction. Malden, MA: Blackwell, 2004. Print. 